\author{
A.Zh. Tyshtikbayeva ${ }^{1}$, A.T. Zhanseitov ${ }^{2}$, E.V. Borisova ${ }^{3}$, A.E. Turusbekov ${ }^{4}$ \\ ${ }^{1,2}$ Ye.A. Buketov Karaganda State University, Kazakhstan \\ ${ }^{3}$ Russian State Academy of Intellectual Property, Russia \\ ${ }^{4}$ Astana IT University, Kazakhstan

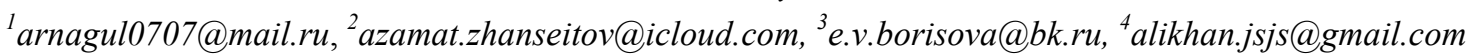 \\ ${ }^{1}$ https://orcid.org/0000-0002-5784-1367, ${ }^{2}$ https://orcid.org/0000-0001-9495-0530, \\ ${ }^{3}$ https://orcid.org/0000-0003-1362-5213, ${ }^{4}$ https://orcid.org/0000-0003-4324-5123
}

\title{
Cryptocurrency: permanent money substitute or another temporary trend
}

\begin{abstract}
Purpose: To identify that the cryptocurrency can be distinguished as a real-money equivalent in Kazakhstan in the near future.

Methods: a SWOT (strengths- weaknesses- opportunities- threats) analysis supported with the results of a survey in Nur-Sultan city.

Results: The majority of surveyed people claim that they refuse to use cryptocurrency due to its complexity and it demonstrably illustrates that people are not sure in new technologies' potential, while the SWOT analysis proved that there certainly is a chance for the cryptocurrency to substitute money due to numerous possibilities.

Conclusions: Undoubtedly, the cryptocurrency is capable to carry out ordinary cash's functions and fully supplant it in the nearest future, offering such focal points as mechanized tax collection, robotized protections, and becoming globally acknowledged money. Although there are several obstacles as the cryptocurrency's instability, administrative weight, and unwillingness of individuals to its integration into our everyday lives, the cryptocurrency can be a lasting money substitute, but the humankind needs more time to acknowledge it as the chief device.
\end{abstract}

Keywords: cryptocurrency, blockchain, bitcoin, decentralization, transaction, database, privacy, encryption.

\section{Introduction}

This article examines various features of the cryptocurrency, a matter of which blew out in the middle of 2017 after its prices' skyrocketing. It sparked a heated discussion al around the globe in order to figure out whether this invention is an ultimate money substitute or a regular transitory trend. It is assumed that the cryptocurrency is expecting high amount of uncertainty towards itself and there is no wonder why.

In this section of the article, background information about cryptocurrency will be presented. A cryptocurrency is a type of digital currency that is registered by a decentralized payment system meaning there is no internal or external administrator or any equivalent (Garrick and Michel, 2017). The cryptocurrency represents a number indicating the amount of data of settlement units, which is recorded in the corresponding position of the information package of the Data Transfer protocol and is often not even subject to encryption, as well as all other information about transactions between addresses of the system (Arvind et al., 2016).

Although cryptocurrency got its fame in mid-2017, developers designed this currency a long time ago. The idea of encrypting confidential payments had been in use since 1990 at DigiCash company, founded by David Chaum until his company bankrupt in 1998. However, it was not close to cryptocurrency we know today as it was centralized. The term "cryptocurrency" risen in usage after the appearance of the "Bitcoin" payment system, which was developed in 2009 by a person or group of people under the pseudonym Satoshi Nakamoto (no identity has been established) (Arvind et al., 2016). The financial crisis of 2008 contributed to the success of Bitcoin as the population has lost trust in banking and controlled financial organizations. At that time, Bitcoin offered independence from the government or any other centralized influence from the third parties, which made it appealing for people. 


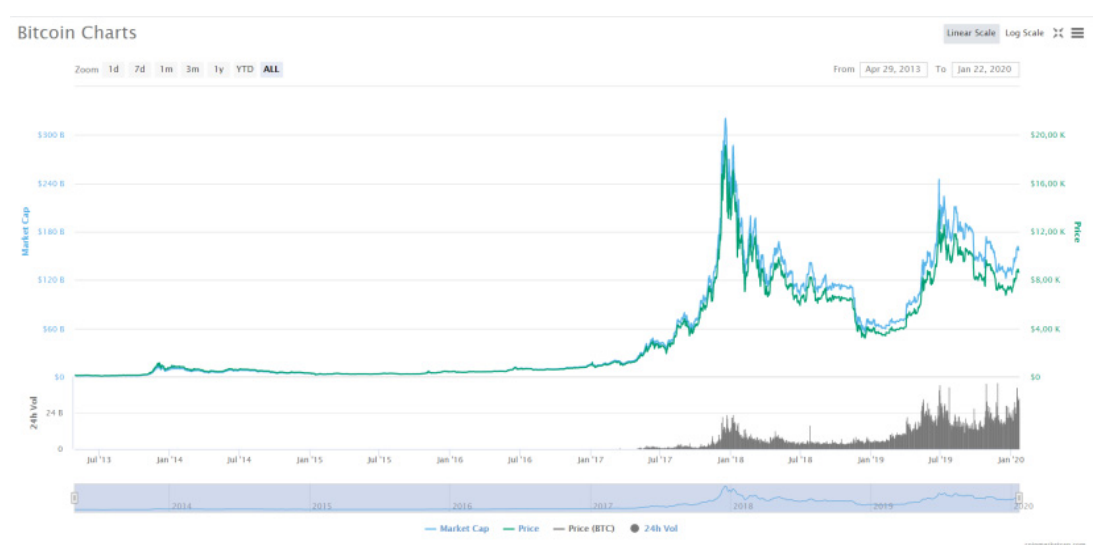

Figure 1.0 Bitcoin's capitalization and price over time

Note - Source (Singh and Singh, 2016)

The Figure 1.0 demonstrates the Bitcoin's capitalization and price starting from the April of 2013 until the January of 2020. The Bitcoin's price depends on its demand; therefore, we can identify the popularity of Bitcoin by looking at its price. From the April of 2013 until the March of 2017, the price remained at the same level of 300-400 USD. Then, it rose exponentially until it reached the peak of over 18,000 USD in the December of 2017. After that, it was falling in price explosively until the January of 2019. Again, the price started to rise steadily until the July of the same year and started to unpredictably fluctuate until now. The overall trend shows that the price of Bitcoin is unstable and unpredictable (Coinmarketcap company, 2020).

Bitcoin uses some essential technologies. Cryptographic methods are often used to provide the system protection, but all transactions between addresses of the system can be seen online. Bitcoin uses a continuous sequential chain of blocks containing information known as Blockchain to protect the system and provide confidential transactions (Ryan, 2015). Bitcoins exist only as records in a replicated distributed database, in which all transactions are stored online, indicating the bitcoin addresses of senders/recipients, but with no information about the real owner of these addresses (Ryan, 2015). There are no separate records in the database about the current number of bitcoins held by any owner. However, the user can easily calculate the total amount of money using information about transactions. For instance, you got two bitcoins from your first transaction, one bitcoin from the second transaction, and sent one bitcoin to another user as your third transaction overall resulting in two bitcoins in your wallet.

The cryptocurrency has its specific features:

1. Decentralization. The blockchain technology works based on peer-to-peer transactions that are not controlled or influenced by third parties. It develops trust between the users and the system.

2. Immutability. Any information remains immutable and constant after being encrypted in the blocks. The further changes are saved to the next block connected to the previous block creating a chain of blocks.

3. Transparency. You can easily find the open course code of Bitcoin, the information about transactions, and the data about the credibility of the users.

4. Confidentiality. The transaction does not contain any confidential information: it contains data only about address of sender/recipient, but no information about who owns them.

\section{Literature Review}

Cryptocurrencies have considered a relatively low profile in 2019 following an outstanding increase in 2017 and then huge crash in 2018. What are expectations in 2020? Here are presented opinions of several experts of this sphere.

Tim Draper, legendary VC, founder of Draper Associates and DFJ, and author of "How to Be the Startup Hero" says that the globe is almost ready for a financial and banking transformation. Engineers and product developers have put their efforts together to bring Bitcoin to general usage and distribution. Within a short time, there will be no reason to pay credit card fee for banks from 2.5 percent up to 4 percent every time. Bitcoin is a frictionless transaction. Similar to other tokens like Tezos, Ethereum, and Bitcoin Cash become more prevalent. My forecast is a $\$ 250,000$ Bitcoin price by 2022 or the first quarter of 2023 .

Judd Rosenblatt, founder and CEO of AE Studio, an Agile web development and data science consulting firm states that whether you are currently investing in cryptography should depend upon whether you believe in the future of blockchain. It did not meet all expectations at once because almost any other destruc- 
tive technology improves along the path. Investing in crypto now could be like picking up Amazon stock for less than IPO price, or it could be like stocking up on Betamaxes on clearance. Only time will tell. Our developers at AE Studio work with blockchain companies like Protocol Labs, and we're constantly impressed with the progress and innovation that's happening in the space. Blockchain technology is developing fast and expected to be essential; so, I think of crypto as an excellent long-term opportunity, despite high-risk, investment. If you think so as well, my No. 1 piece of exhortation is to contribute no more than you will bear to lose in things like BTC and ETH, which can likely emphatically connect with blockchain selection. And hodl long term!"

Lorenzo Pellegrino, CEO of Skrill, NETELLER, and Income Access at Paysafe; connect with Lorenzo on LinkedIn" "While the markets may have slammed, the development of the foundation empowering cryptocurrency has never truly moderated down, particularly at Skrill. Concurring to numerous industry specialists, the space is presently steady, more develop, and prepared to move into its following stage. To see something that begun as no more than a thought within the profundities of the web produce an unused environment and develop into a multibillion-dollar resource lesson is nothing brief of momentous to me. The largest companies and nations within the world now discuss cryptocurrency as a reasonable cash of long term. I would fairly remind budding financial specialists that exchanging in such an energetic space implies the stakes are higher. Legitimate investigate and chance administration are essential."

Dan Schatt, co-founder and CEO of Cred: "Remember the noteworthy financial crash 10 a long time back, when numerous people's life reserve funds were wiped out? That's when Bitcoin was born; a cryptocurrency made mostly in reaction to the driving monetary mediators that made a difference bring down the economy. Bitcoin has ended up more broadly received for a few reasons. It encompasses an unsurprising swelling rate since as it were 21 million will ever be delivered. It is borderless, with straightforwardness that no bank can coordinate. And it is not trusted because the framework was planned so you do not believe anybody else for it to operate. It has been pronounced dead by journalists 378 times, counting 40 times this year. But Bitcoin will not pass on since it can be trusted more than most government monetary forms. There is no middle person. And in a world full of fizzled money related mediators, that is an enormous deal."

Johann Polecsak, co-founder and CTO of QAN blockchain platform: "The cryptocurrency decay was great for the showcase since it instructed speculators that not all coins are as glossy as they might appear. We continuously empower making choices based on genuine showcase esteem rather than theory. How do you degree the esteem of a token without profound information? Seek for stages that can be coordinates into undertaking forms to upgrade their workflows. That's how mass selection happens. When the web begun, companies had to coordinate the innovation to convey substance for clients to expend. That is where we are presently with cryptocurrency, but we lost stages that companies can use and are able of working on a worldwide scale. That is likely why the ROI of tokens from the best 11 blockchain stages (WAVES, EOS, NEO, ETH, LSK, ADA, MATIC, FTM, ZIL, TRX, and ALGO) midpoints more than 1,000 percent."

Alex Althausen, CEO of StormGain, a cryptocurrency trading platform: "In 1997, Amazon went open at $\$ 18$ per share. The stock developed to over $\$ 300$ per share some time recently falling to beneath $\$ 6$ when the dot-com bubble burst in 2001. Quick forward to 2018: Amazon comes to $\$ 2,050$ per share and got to be the moment U.S. company to obscure $\$ 1$ trillion in stock advertise esteem. Numerous speculators see this design happening with cryptocurrency. Bitcoin skyrocketed from approximately $\$ 3,600$ per coin to over $\$ 19,000$ in 2017 . At that point it fell underneath $\$ 3,500$ sometime recently climbing to $\$ 12,000$ in 2019 . My counsel is to keep an eye on the Bitcoin splitting in 2020, which can drastically alter the cryptocurrency supply and request condition. I accept it will be recollected as an authentic point of reference for Bitcoin and the whole industry. It might be the turning point that takes Bitcoin from a specialty, unsteady resource to a standard frame of payment" (Oracles, 2019).

"We are approximately to roll out a few critical modern requirements," Mr. Mnuchin said amid a hearing some time recently the Senate Back Committee. "We need to create beyond any doubt that innovation moves forward; on the other hand, we need to create beyond any doubt cryptocurrencies are not utilized for the comparable of ancient Swiss mystery number banking." Mr. Mnuchin did not give points of interest of what the controls would involve. He said that they would give more noteworthy straightforwardness so that law authorization might see where cash was going and guarantee that it was not being utilized to help cash washing (Rappeport and Smialek, 2020).

Erik Voorhees, cryptocurrency entrepreneur says, "It is that narrative of human development under which we now have other fights to fight, and I would say in the realm of Bitcoin it is mainly the separation of money and state." 
Caleb Chen London Trust Media: "In the next few years, we are going to see national governments take large steps towards instituting a cashless society where people transact using centralized digital currencies. Simultaneously, the decentralized cryptocurrencies - that some even view as harder money - will see increased use from all sectors" (Rosic and Blockgeeks, 2020).

What is a blockchain? In short, it is a disintermediating technology or it removes the necessity for middlemen and trusted third-parties. In combination with other technologies, blockchains have the potential to disintermediate many areas of life, from banking to information storage to voting to the making and sharing of goods and services (Clendaniel, 2017).

Some economic analysts foresee a huge alter in crypto is forthcoming as institutional money enters the market. Besides, there is the possibility that crypto will be drifted on the Nasdaq, which would further add credibility to blockchain and its uses as an alternative to conventional currencies. Some people anticipate that all that crypto needs is a verified exchange traded fund (ETF). An ETF would certainly make it easier for individuals to invest in Bitcoin, but there still should be the demand to want to contribute in crypto, which some say may not automatically be created with a fund.

In the beginning of 2017, there were only a few small operational crypto funds trading coins for limited partners. In June, there have been seen pitches for dozens of them. Traditional institutions with traditional bases are raising some of these funds. Others are running or planning to run ICO processes themselves (Sam Lessin, 2020).

Bitcoin could be a decentralized cash that employments peer-to-peer innovation, which empowers all capacities such as money issuance, exchange handling and confirmation to be carried out collectively by the arrange. Whereas this decentralization renders Bitcoin free from government manipulation or obstructions, the flipside is that there's no central specialist to guarantee that things run easily or to back the esteem of a Bitcoin. Bitcoins are made carefully through a "mining" handle that requires capable computers to fathom complex calculations and crunch numbers. They are as of now made at the rate of 25 Bitcoins each 10 minutes and will be capped at 21 million, a level that's anticipated to be come to in 2140 .

These characteristics make Bitcoin distinctive from a fiat currency, which is backed by the full confidence and credit of its government. Fiat currency issuance is an exceedingly centralized movement directed by a nation's central bank. While the bank controls the amount of currency issued according to its monetary policy objectives, in theory, there is no upper limit to the amount of such currency issuance. Moreover, local currency deposits are generally insured against bank failures by a government body. Bitcoin, on the other hand, has no such support mechanisms. The value of a Bitcoin is entirely dependent on what investors are willing to pay for it at a point in time. As well, if a Bitcoin exchange folds up, clients with Bitcoin balances unable to return them back.

The future viewpoint for bitcoin is the subject in heat debate. Whereas the financial media is proliferated by so-called crypto-evangelists, Harvard University Professor of Economics and Public Policy Kenneth Rogoff recommends that that the "overwhelming sentiment" among crypto advocates is that the whole "market capitalisation of cryptocurrencies seem detonate over the another five a long time, rising to \$5-10 [trillion]."

The noteworthy instability of the resource course is "no reason to panic," he says. Still, he tempered his positive thinking which of the "crypto evangelist" see of Bitcoin as computerized gold, calling it "nutty," expressing its long-term esteem is "more likely to be $\$ 100$ than $\$ 100,000$."

Rogoff contends that not at all like physical gold, Bitcoin's utilize is constrained to exchanges, which makes it more defenseless to a bubble-like collapse. Also, the cryptocurrency's energy-intensive confirmation handle is "vastly less efficient" than frameworks that depend on "a trusted central specialist like a central bank."

Some of the impediments that cryptocurrencies presently confront - such as the fact that one's digital fortune can be eradicated by a computer crash, or that a hacker may scour a virtual vault - may be overcome in time through innovative progresses. What will be more difficult to overcome is the fundamental conundrum that bothers cryptocurrencies - the more well known they gotten to be, the more control and government investigation they are likely to pull in, which dissolves the basic premise for their existence.

Whereas the number of vendors who acknowledge cryptocurrencies has constantly expanded, they are still exceptionally much in the minority. For cryptocurrencies to become more widely utilized, they ought to begin with picking up far reaching acceptance among buyers. However, their relative complexity compared to customary monetary standards will probably deter most individuals, except for the technologically adept. 
A cryptocurrency that tries to become a small piece of the mainstream financial framework may force to satisfy broadly unique criteria. It ought to be mathematically complex (to maintain fraud and attacks from hacker) but simply understand by customers; decentralized but with adequate consumer shields and security; and preserve user anonymity without being a conduit for tax evasion, money laundering and other nefarious activities. Since these are imposing criteria to fulfill, is it conceivable that the foremost popular cryptocurrency in a number of years' time might have qualities that drop in between heavily-regulated fiat monetary forms and today's cryptocurrencies? Whereas that plausibility looks farther, there's small question that as the driving cryptocurrency at show, Bitcoin's victory (or need thereof) in overseeing the challenges it faces may decide the fortunes of other cryptocurrencies inside the long time ahead (Barone, 2020).

\section{Methods}

To examine the potential of this trend, it was decided to make a SWOT-analysis to figure different sides of the cryptocurrency issue. The benefits of using this exact method will be useful in the further conclusions. It will contribute in understanding if strengths outweigh weaknesses or if it is possible to overcome threats using possibilities or strengths. The SWOT analysis will be presented and supported by the results of a survey (conducted by the authors).

The survey was conducted during the summer of 2019 in Nur-Sultan, the capital of the Republic of Kazakhstan. The number of participants is 342 with 47 percent being female. Participants age ranges from 10 to 54 equally distributed. Survey contained five closed-ended questions and two open-ended questions on the topic of cryptocurrency and its use. The limitation of the survey is that more than 95 percent of participants were the residents of Nur-Sultan, meaning the results might be applied only to the residents of that city.

\section{Results}

The SWOT analysis:

Strengths. According to, the maximum number of bitcoins is twenty-one million and it cannot be changed. The limited number of bitcoins gives it a strength of preventing inflation and problems caused by monetary policy of the government.

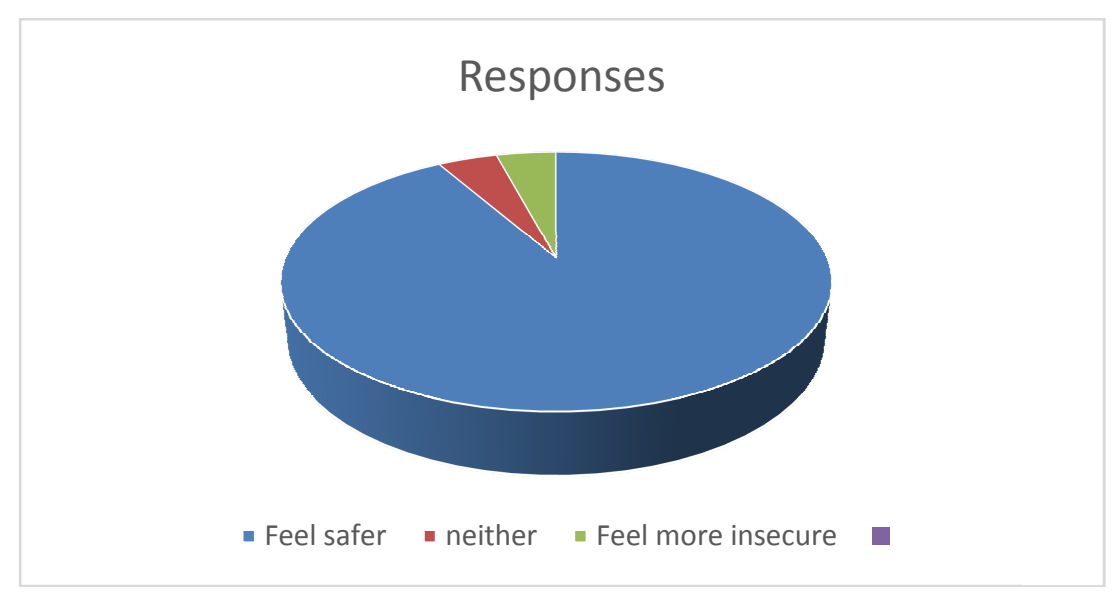

Figure 2.0 Responses on feeling safety using cryptocurrency.

Note - made by authors

In addition, the decentralization of the system makes the users more comfortable and safer using the currency. This was proven by the survey showing that 91.7 percent of cryptocurrency users feel safer that transactions are not influenced by third parties (Figure 2.0). Next, the currency can be used globally without any boundaries, meanwhile other currencies are used within the boundaries of the countries. 6 out of 24 participants who are using cryptocurrencies reported that they made international transactions, and all of them reflected positively on the speed of the transactions. Moreover, the cryptocurrency provides financial services to users with low access to banking systems (Zheng Z. et al, 2017). It gives more people opportunity to use financial services catalyzing the economic processes in the country and provides the equality among people opportunities.

Weaknesses. Even though Bitcoin is very popular across the Internet users, the actual usage of cryptocurrency is not widely spread. This was proven by the results of the survey indicating that out of all 342 participants only 24 participants use or have used any kind of cryptocurrency. 


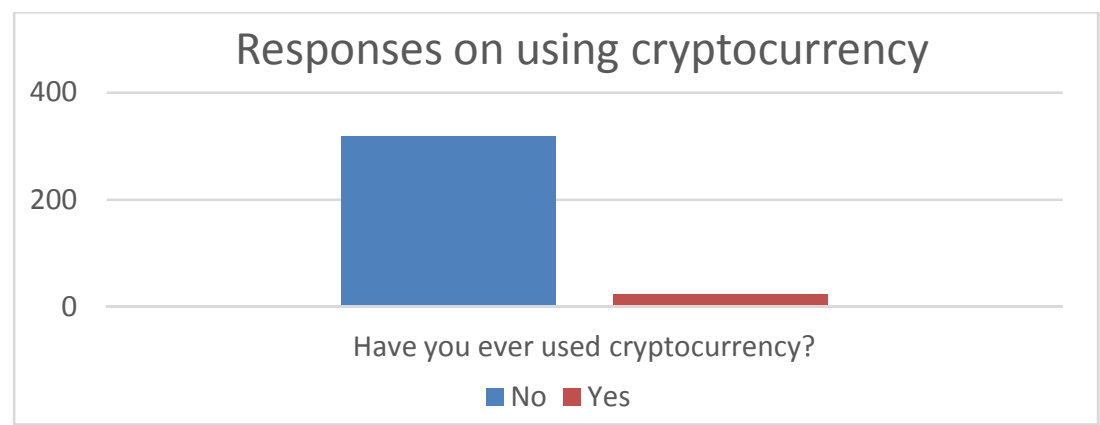

Figure 3.0 Responses on using cryptocurrency

Note - made by authors

Next, the cryptocurrency is dependent on its reputation. For instance, the number of cryptocurrency users dropped after the 'Silk road' incident happened at which people started using cryptocurrency to buy drugs on the Darknet (the illegal side of the Internet). In addition, one of the weaknesses is vulnerability to cyberattacks such as social engineering and DDoS (Singh and Singh, 2016). The cryptocurrencies can carry out the limited number of transactions simultaneously meaning that DDoS attacks can stop the work of the server for other users. The social engineering might be the way the hackers get the private keys from the asymmetric encryption of the wallet. However, the survey contradicts this fact as it shows that none of cryptocurrency users faced the DDoS attack and never experienced losing private keys. Even though cryptocurrencies do not share the information about the users, there are still ways to track the location from which the transaction was initiated. The great example is 'Silk road' incident that shows that illegal transactions can be tracked.

Opportunities. The cryptocurrency can be used to facilitate processes within the country using smart contracts (electronic algorithm that runs the several instructions after the certain conditions being fulfilled). The taxation can be automated using smart contract: the receiver of the transaction can be government, and the transaction will be sending the taxes each week automatically. In addition, cryptocurrency can change the world economy by replacing all the other currencies eliminating the dependencies of other currencies on USD (David et al., 2018). In addition, the insurance can be automated with smart contracts. If the insurance company enters a smart contract with the client, the contract will be executed automatically when an insured event occurs, and the policyholder will receive a refund immediately and without visiting the office. Finally, the automation of penalties/fines (automation of accrual of fines when performing (non-performing) certain actions.

Threats. The cryptocurrency providing everyone with ability to use financial services and privacy can stimulate shadow economy in the country. In addition, the people might be not ready to use blockchain as they are not used to it.

The results of the survey showcase that slightly more than two fifths $(41.5 \%)$ are not using cryptocurrencies because they believe that it is too complex. Just under two fifths (39\%) claim that this system is almost the same as e-money, and approximately one in ten (10.5\%) say that they prefer other assets (Figure 4.0).

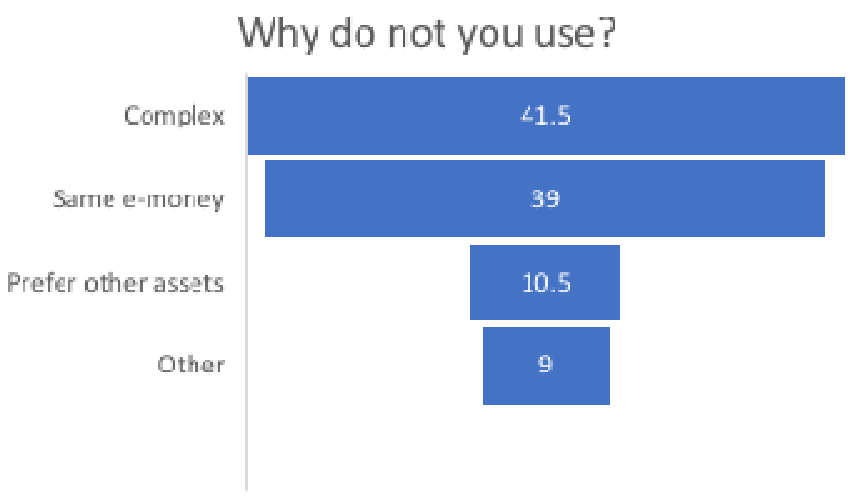

Figure 4.0 The reasons of not using cryptocurrency 


\section{Discussions}

The results of the survey show that society is not ready to accept cryptocurrency as the part of their everyday life. Moreover, cryptocurrency can change in price extremely fast making it unreliable for the constant use. For the crypto market, there are threats from regulatory authorities. Just as the Internet is censored in some parts of the world. Cryptocurrencies face regulatory pressure when it threatens local currencies and governments. For example, China has tried to restrict cryptocurrency activity with limited success (Yukun and Aleh, 2018). The majority believes that using cryptomoney is too sophisticated, and it is much easier to continue using traditional money. However, it is clear that we need to keep up with the times, and one way or another a different system will replace the current inefficient one. There is no point in delaying the inevitable. As the financial medium, the cryptocurrency provides high security, adaptability and many business benefits such as lower transaction fees.

The SWOT analysis made it possible to identify the main advantages, disadvantages, as well as opportunities and threats in the execution of this project. The revealed opportunities strongly suppress weaknesses and make it possible to turn them into strengths of the cryptocurrency. However, some of them can still pose a threat, and thereby cause fear in people. For instance, financial loss will definitely be a disaster for any person. This can be a result of the data loss in the web that a certain genius hacker or high-skilled programmer is easily able to do. In case the system of cryptocurrency is upgraded, it will become the most secure system out of all ever existing, showing its dominance towards others. By improving safety the disadvantage can turn into a strong benefit.

\section{Conclusion}

According to the results of both SWOT analysis and survey, it is can be concluded that cryptocurrency has its potential in replacing conventional money because it is able to carry out all the functions that the usual money does and can bring several benefits such as automated taxation, automated insurance, and being internationally accepted currency. However, there are numerous risks as the cryptocurrency is not stable, faces regulatory pressure, and people are not ready to use it in their daily lives. Nevertheless, these kinds of threats do not need to be feared of, as their further development would easily assist in getting rid of the main weaknesses. The main point is that people are still having trouble in comprehension and adjustment to new technologies, which is considered to be the most significant idea out of all presented in the list. The fact that humankind are not ready plays the key role in implementation cryptocurrency into everyday use. It is preferable that before the full introduction there would be some guide and briefing, so that people will understand what they need to do, thus making it clear that the system only looks complex at the first sight. Therefore, the cryptocurrency definitely can be a permanent money substitute, but the humanity needs time to accept it as the main tool.

\section{References}

Arvind N. et al, pg. 31-56, 2016: Bitcoin and Cryptocurrency Technologies: A Comprehensive Introduction. https://books.google.kz/books?hl=ru\&lr=\&id=LchFDAAAQBAJ\&oi=fnd\&pg=PP1\&dq=cryptocurrency\&ots=ArrNeX 1HnI\&sig=vM7RlgqTuG1BTNA7ku0FSJ18zv8\&redir_esc $=y \# v=$ onepage \&q $=$ cryptocurrency\&f=false

Barone, A. (2020, January 29). The Future of Cryptocurrency: https:/www.investopedia.com/articles/forex/091013/future-cryptocurrency.asp

Clendaniel, M. (2017, October 18). Can Basic Income Plus The Blockchain Build A New Economic System?: https:/www.fastcompany.com/40482312/can-basic-income-plus-the-blockchain-build-a-new-economic-system

Coinmarketcap company, 2020. Retrieved from https://coinmarketcap.com/currencies/bitcoin/

David L., Li G., \& Yu W., 2018: Cryptocurrency: A New Investment Opportunity? Retrieved from https://jai.pmresearch.com/content/20/3/16.short

Garrick H. \& Michel R., 2017: Global Cryptocurrency benchmarking study. Retrieved from https://www.crowdfundinsider.com/wp-content/uploads/2017/04/Global-Cryptocurrency-Benchmarking-Study.pdf

Lessin Sam (2020). Seven Key Questions in the Cryptocurrency World: https://www.theinformation.com/articles/sevenkey-questions-in-the-cryptocurrency-world

Oracles, T. (2019, December 19). Is Cryptocurrency Coming Back or Going Away for Good? 6 Experts Weigh In.: https://www.entrepreneur.com/slideshow/343984

Petrov V.U., \& Bortsova A. V. (2018, July 31). CRYPTOCURRENCY AS THE NEWEST FORM OF MONEY IN THE MODERN ECONOMY: https:/www.newscientist.com/article-topic/bitcoin-cryptocurrency/

Rappeport, A., \& Smialek, J. (2020, February 12). Treasury to Roll Out Cryptocurrency Rules: https://www.nytimes.com/2020/02/12/us/politics/treasury-cryptocurrency.html 
Rosic, A., \& Blockgeeks. (2020, February 8). What is Cryptocurrency? [Everything You Need To Know!]: https://blockgeeks.com/guides/what-is-cryptocurrency/

Ryan F., 2015: An Analysis of the Cryptocurrency Industry. Retrieved from https://repository.upenn.edu/cgi/viewcontent.cgi?article=1133\&context=wharton_research_scholars

Singh S. \& Singh N., 2016: Blockchain: future of financial and cyber security. Retrieved from https://ieeexplore.ieee.org/abstract/document/7918009

Yukun L. \& Aleh T., 2018: Risks and Returns of Cryptocurrency. Retrieved from https://www.nber.org/papers/w24877

Zheng Z. et al, 2017: An overview of Blockchain technology: architecture, consensus, and future Trends. Retrieved from https://ieexplore.ieee.org/abstract/document/8029379

\title{
А.Ж. Тыштикбаева, А.Т. Жансейтов, Е.В. Борисова, А.Е. Турусбеков
}

Криптовалюта: тұрақты ақша ауыстыру немесе басқа уақытша тренд

\begin{abstract}
Аңдатnа
Maқcambl: Қазақстандағы нақты ақшаның баламасы ретінде криптовалютаны бөліп алуға болатынын анықтау.

Әdici: SWOT-талдау (күшті жақтары-әлсіз жақтары-мүмкіндіктер-кауіптер), сауалнама нәтижелері.

Қорытынды: Сұралғандардың көпшілігі криптовалютаның күрделілігіне байланысты қолданудан бас тартады және бұл адамдар жаңа технологиялардың әлеуетіне сенімді емес екенін көрнекі көрсеткен, ал SWOTталдау криптовалютаның көптеген мүмкіндіктеріне байланысты ақшаны ауыстыру мүмкіндігі бар екенін дәлелдеген.

Тұжырымдама: Криптондық валюта әдеттегі қолма-қол ақша функциясын орындауға және жақын болашақта оларды толығымен ығыстыруға қабілетті, механикаландырылған салық жинау, роботталған қорғау және дүниежүзілік танылған ақша ретінде үйлестіру орталықтарын ұсынады. Криптовалюта тұрақсыздығы, әкімшілік салмағы және жеке тұлғалардың біздің күнделікті өмірімізге интеграциялауды қаламайтыны сияқты бірнеше кедергілер бар болса да, криптовалюта ұзақ уақыт ақша алмастыруы мүмкін, бірақ адамзат оны басты құрылғы деп тану үшін көп уақыт қажет.

Кілm сөздер: криптовалюта, блокчейн, орталықсыздандыру, транзакция, деректер қоры, құпиялылық, шифрлау.
\end{abstract}

\section{А.Ж. Тыштикбаева, А.Т. Жансейтов, Е.В. Борисова, А.Е. Турусбеков}

\section{Криптовалюта: постоянная денежная замена или другой временный тренд}

\section{Аннотация}

Цель: Определить, можно ли выделить криптовалюту как эквивалент реальных денег в Казахстане.

Memoдbl: SWOT-анализ (сильные стороны-слабые стороны-возможности-угрозы), подкрепленный результатами опроса.

Pезультаты: Большинство опрошенных утверждают, что они отказываются использовать криптовалюту из-за ее сложности, и это наглядно иллюстрирует, что люди не уверены в потенциале новых технологий, в то время как SWOT-анализ доказал, что у криптовалюты, безусловно, есть шанс заменить деньги из-за многочисленных возможностей.

Bblвoды: Несомненно, криптовалюта способна выполнять функции обычных наличных денег и полностью вытеснить их в ближайшем будущем, предлагая такие координационные центры, как механизированный сбор налогов, роботизированная защита и став всемирно признанными деньгами. Хотя существует несколько препятствий, таких как нестабильность криптовалюты, административный вес и нежелание отдельных лиц интегрировать ее в нашу повседневную жизнь, криптовалюта может быть длительной заменой денег, но человечеству нужно больше времени, чтобы признать ее главным устройством.

Ключевые слова: криптовалюта, блокчейн, биткоин, децентрализация, транзакция, база данных, конфиденциальность, шифрование.

\section{References}

Arvind N. et al. Bitcoin and Cryptocurrency Technologies: A Comprehensive Introduction. (https://books.google.kz/books?

$\mathrm{hl}=\mathrm{ru} \& \mathrm{lr}=\& \mathrm{id}=\mathrm{LchFDAAAQBAJ} \& \mathrm{oi}=$ fnd\&pg $=$ PP1\&dq= cryptocurrency\&ots=ArrNeX1HnI\&sig=vM7RlgqTuG1B TNA7ku0FSJ18zv8\&redir_esc $=\mathrm{y} \# \mathrm{v}=$ onepage $\& \mathrm{q}=$ cryptocurrency\&f=false).

Barone, A. The Future of Cryptocurrency.- (https://www.investopedia.com/articles/forex/091013/futurecryptocurrency.asp).

Clendaniel, M. Can Basic Income Plus The Blockchain Build A New Economic System?. (https://www.fastcompany.com/40482312/can-basic-income-plus-the-blockchain-build-a-new-economic-system).

Coinmarketcap company. — (https://coinmarketcap.com/currencies/bitcoin/). 
David L., Li G., \& Yu W. Cryptocurrency: A New Investment Opportunity?. - (https://jai.pmresearch.com/content/20/3/16.short).

Garrick H. \& Michel R., Global Cryptocurrency benchmarking study. — (https://www.crowdfundinsider.com/wpcontent/uploads/2017/04/Global-Cryptocurrency-Benchmarking-Study.pdf).

Lessin Sam. Seven Key Questions in the Cryptocurrency World // https://www.theinformation.com/articles/seven-keyquestions-in-the-cryptocurrency-world).

Oracles, T. Is Cryptocurrency Coming Back or Going Away for Good? 6 Experts Weigh In. (https://www.entrepreneur.com/slideshow/343984).

Petrov V.U., \& Bortsova A. V. CRYPTOCURRENCY AS THE NEWEST FORM OF MONEY IN THE MODERN ECONOMY. - (https://www.newscientist.com/article-topic/bitcoin-cryptocurrency/).

Rappeport, A., \& Smialek, J. Treasury to Roll Out Cryptocurrency Rules. (https://www.nytimes.com/2020/02/12/us/politics/treasury-cryptocurrency.html).

Rosic, A., \& Blockgeeks. What is Cryptocurrency? [Everything You Need To Know!]. (https://blockgeeks.com/guides/what-is-cryptocurrency/).

Ryan F. An Analysis of the Cryptocurrency Industry. - (https://repository.upenn.edu/cgi/viewcontent.cgi? article $=1133 \&$ context $=$ wharton research scholars $)$.

Singh S. \& Singh N. Blockchain: future of financial and cyber security. (https://ieeexplore.ieee.org/abstract/document/7918009).

Yukun L. \& Aleh T. Risks and Returns of Cryptocurrency. — (https://www.nber.org/papers/w24877).

Zheng Z. et al. An overview of Blockchain technology: architecture, consensus, and future Trends. (https://ieeexplore.ieee.org/abstract/document/8029379). 